\title{
Geotourist attractions of the Kleśnica Valley
}

\section{Atrakcje geoturystyczne doliny Kleśnicy}

\section{Stanisław Koszela ${ }^{1}$, Aneta Marek $^{2}$}

${ }^{1}$ Adam Mickiewicz University in Poznań, Institute of Geology, ul. Maków Polnych 16, 61-606 Poznań

${ }^{2}$ Pomeranian Academy, Institute of Geography and Regional Studies, ul. Partyzantów 27, 76-200 Słupsk e-mail: ${ }^{1}$ stanko@amu.edu.pl; ${ }^{2}$ kornika@wp.pl
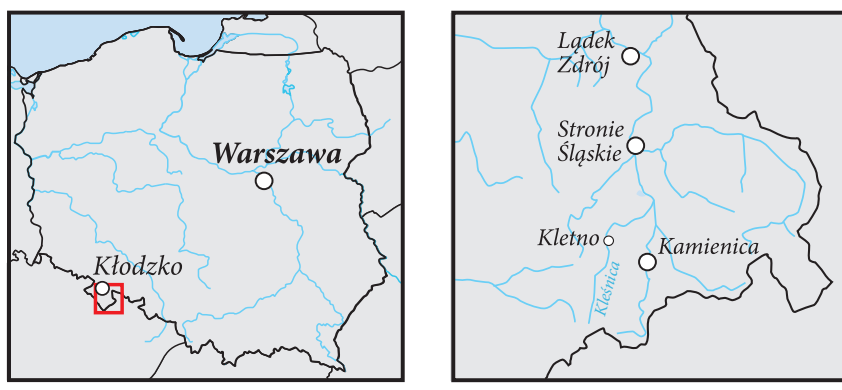

Abstract: Geotourist attractions of the Kleśnica Valley, located in the Śnieżnik Massif the Eastern Sudetes were presented in this article. Many valuable geological objects as well as the remains of ancient works mining, constituting the valuable cultural-historical legacy are located in the area of the discussed valley. These objects include Bear Cave, marble quarry, Marianna Spring, spoil-heap, Museum of the Earth, mine of uranium and "Gracious Stone" lime kiln.

Keywords: geotourism, Kleśnica Valley, Bear Cave, quarry

Treść: W artykule zaprezentowano walory geoturystyczne doliny Kleśnicy, położonej w Masywie Śnieżnika w Sudetach Wschodnich. $W$ rejonie omawianej doliny znajduje się wiele cennych stanowisk geologicznych, a także pozostałości dawnych prac górniczych, stanowiacych cenne dziedzictwo kulturowo-historyczne. Wśród tych obiektów znajduja się Jaskinia Niedźwiedzia, kamieniołomy marmuru, odwiert „Źródlo Marianna”, hałda poeksploatacyjna rud uranu, Muzeum Ziemi Geologiczne - Kletno, sztolnia w nieczynnej kopalni uranu i wapiennik „Łaskawy Kamień”.

Slowa kluczowe: geoturystyka, Dolina Kleśnicy, Jaskinia Niedźwiedzia, kamieniołomy

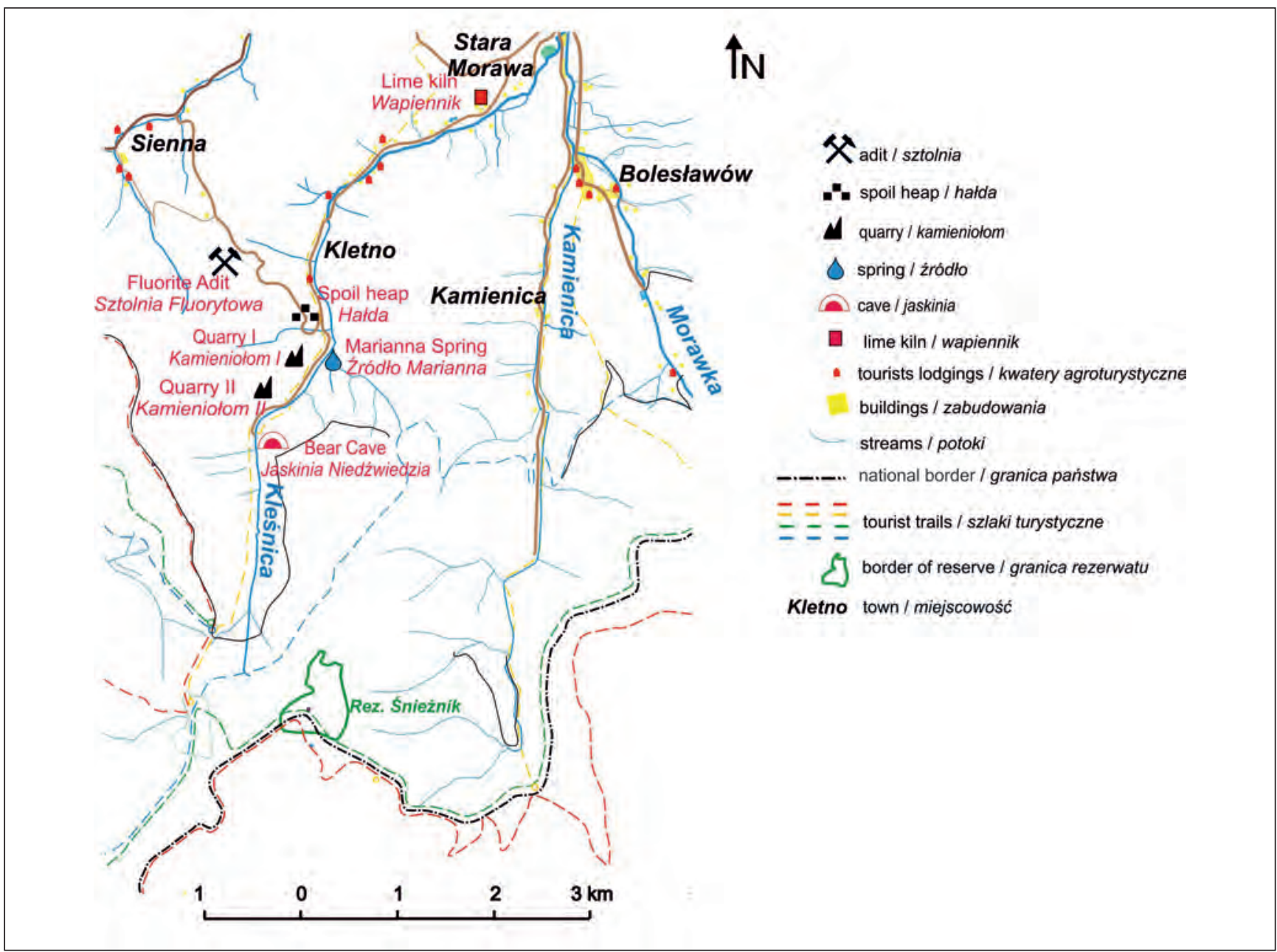

Fig. 1. Location of Kleśnica Valley against Śnieżnik Massif • Położenie doliny Kleśnicy na tle Masywu Śnieżnika 


\section{Introduction}

The diversity of the natural world and growing interest in geology has led to the emergence of a new purpose of tourist trips. In recent years, a new discipline of tourism, i.e. geotourism has gained more and more recognition. Geotourism is a combination of recreation, leisure and education, and is focused on exploring geological objects and understanding geological phenomena and processes associated with them. Practicing geotourism allows you to answer the questions: when, why and how various forms and elements of inanimate nature were created (www.mos.gov.pl). Because of its diversity, geotourism is often combined with other forms of qualified tourism, active tourism and recreation, the practicing of which requires appropriate skills and equipment and often also qualifications, such as rock climbing, caving, canoeing, glacier trekking (Gray, 2004). Geotourist activities can therefore be considered at three levels, consisting in:

- tourism focused on geological aspects of the natural environment and cultural heritage;

- providing materials to help tourists understand the geological phenomena and their relationship with human life (maps, guidebooks, catalogues, videos, information boards, leaflets, etc.);

- development of research methods, tools and techniques in various scientific disciplines (Miśkiewicz et al., 2007).

\section{Geological location of the Kleśnica Valley}

The Kleśnica Valley is located in the Eastern Sudetes in the Śnieżnik Massif micro-region. The valley is formed by the Kleśnica stream, flowing from the northern slopes of Śnieżnik, from an altitude of about $1210 \mathrm{~m}$ a.s.l. It is a left tributary of the Morawka, which it joins at an altitude of $534 \mathrm{~m}$ a.s.l. in Stara Morawa. The total length of the Kleśnica Valley is $8.7 \mathrm{~km}$ (Fig. 1).

In the Kleśnica Valley, three morphologically different sections can be distinguished:

- the upper section from the spring to the $0.6 \mathrm{~km}$ of the course, situated at an altitude of 1210-1030 m a.s.l., with slope processes occurring within the stream channel, with a mean grade of $300 \%$;

- the central section from 0.6 to $3.3 \mathrm{~km}$ of the course, located at an altitude of 1030-730 m a.s.l., with a visible valley, at the bottom of which, as a result of high water, an accumulation terrace with dominant deep erosion starts to occur, with a mean grade of $111 \%$;

- the lower section from 3.3 to $8.7 \mathrm{~km}$ of the course, located at an altitude of 730-534 m a.s.l., characterized by the presence of an accumulation terrace, with a mean grade of 36.3 \%o (Bieroński, 1989).

\section{The geology of the Kleśnica Valley}

The Orlica-Śnieżnik dome is a geological unit of the western Sudetes separated from the eastern Sudetes by the Ramzów overthrust (Teisseyre, 1968). The Upper Nysa trench divides the dome into a western part - the metamorphic unit of the Bystrzyckie and Orlickie mountains and an eastern part - the metamorphic unit of Śnieżnik. The metamorphic unit of Śnieżnik consists of metamorphic rocks of the Młynów-Stronie Group, Śnieżnik gneisses and Gierałtów gneisses formations.

In the Młynów-Stronie Group, a lithologically monotonous formation of Młynowiec is composed of plagioclase paragneisses and mica schists, and a lithologically diverse Stronie Formation, built mainly of mica schists and paragneisses with intercalations including quartzites, amphibolites and marbles. Śnieżnik gneisses (orthogneisses) are medium-to coarse-grained, with the composition of granites, characterized by eye structures, mylonitic lamination and rodding lineation. Gierałtów gneisses are fine-grained, with migmatite structures, characterized by recrystallization and biotite lineation (Smulikowski, 1979; Don et al., 1990). The age of schist formation rocks is assumed to be the late Proterozoic - Early Cambrian, and the age of gneiss formations (based on isotopic dating) at about 500 Ma. The rocks of the Śnieżnik metamorphic unit were metamorphosed also in a high pressure, as evidenced by the occurrence of granulites and eclogites, about 352-329 Ma (Żelaźniewicz, 2003).

In the Śnieżnik metamorphic unit, gneiss antiforms and schists synforms are distinguished. Stare Mesto-Kletno and Bielice-Stronie faults divide the Śnieżnik metamorphic unit into blocks of the Złote and Bialskie, Krowiarki and Śnieżnik mountains. The fault Stare Mesto-Kletno is characterised by the occurrence of mineralization of Fe, $\mathrm{U}$ and $\mathrm{F}$ (Banaś, 1963).

The Kleśnica Valley is located in the southern part of the Śnieżnik Massif. The basis of the river system of the Kleśnica Valley is the Kleśnica stream flowing to the north. Hydrogeological studies indicate the flow of a part of the surface water of the Kleśnica south to the Morava Valley on the Czech side. This phenomenon is caused by the specific geological structure and fracture-karst groundwater environment developed in tectonically fractured and karsted marbles (Kryza, 1982). In the upper part, in the Sienna synform, the Kleśnica Valley is developed in rock of Stronie Formation. In the central part, between the peaks Rudka and Młyńsko, it crosses the Śnieżnik gneisses of the Śnieżnik antiform, and in the lower part it is developed in the rocks of the Stronie synform. In the upper part of the Kleśnica Valley there are rocks of Stronie Formation - mainly mica schists with marble lenses (quarries Kletno I-IV) in which karst systems of Kleśnica developed. Marbles are folded in the form of isoclinal folds, overthrown in a westerly direction. These are mainly calcite-dolomite and dolomite marbles (Koszela, 1997). In the central part, the Kleśnica Valley crosses the Stare Mesto-Kletno dislocation zone, which is situated between the Rudka and Młyńsko massifs built of Śnieżnik gneisses in the eastern and the Stare Mesto-Kletno fault in the western part. The Zawada-Puchaczówka transversal fault divides the dislocation zone into the Kletno deposit zone in the south and the Janowa Góra zone in the north. Among the rocks of the dislocation zone there are both Śnieżnik gneisses and mica schists with insertions of marbles, erlans, amphibolites and quartz veins with fluorite and hematite. The complicated geological structure of the Stare Mesto-Kletno dislocation zone is clearly visible 
in the open to tourists fragment of the old mine on the slopes of Żmijowiec.

The lower part of the Kleśnica Valley is developed in the Stronie synform and crosses rocks of the Stronie Formation, which include mica schists, amphibolites and marbles on the slopes of Janowa Góra, marbles in the quarry "Biała Marianna” on the slopes of Krzyżnik, amphibolites on the peak of Krzyżnik and the schists in the rocks "Three Sisters”. These rocks are mostly covered by weathered rocks and Quaternary sediments and are exposed on the slopes of the surrounding peaks.

\section{Mining history in Kleśnica Valley}

The first records indicating mining traditions in the discussed area date back to 1347. A term "die Clesse" is mentioned and it could have meant a tool or a place for crushing ore. It is assumed that the name gave rise to the village Klessengrund and stream Klessenbach, which currently are Kletno and Kleśnica (Ciężkowski et al., 1996).

The development of mining and metallurgy in the Śnieżnik Massif must have been significantly influenced by the document issued in 1497 by Henry the Elder, the Duke of Ziębice, granting the freedom of mining explorations. This document made it possible not only to reactivate old sites but mainly to construct new iron mines, which was utilised in many villages situated at the foot of the Śnieżnik Massif: Strachocin, Stronie, Kletno, Kąty Bystrzyckie (Ciężkowski, 1989). In the 16th century, there were several records of mines in the Śnieżnik Massif. The existence of other mines in Kletno is indicated by documents of 1520 (St. Paul's adit), 1521 (St. Jacob’s adit) and 1577 Gloomy adit, where silver ore was found to occur. The well promising mining activity in Kletno, Marcinków and Boleslawów was disrupted by the Thirty Years War (16181648), which the political, economic and social effects affected the inhabitants of this land for many years onwards. Although exploration attempts were resumed after 1656 with copper ore exploitation, the end of the 17th century saw the decline of mining in the area (Gluziński, 1960). Mining operations were resumed again for a few years after 1839, at the initiative of Marianne of Orange, Princess of the Netherlands, the owner of Stronie Śląskie, Kamieniec Ząbkowicki and Złoty Stok.

The next period of mining activity started after WW II. In 1947, under a Polish-Soviet agreement on uranium deposits survey on the Polish territory, the first exploratory operations began. They were led by the Soviet geological survey already in 1948 as a result of the case of radioactivity detected on the spoil-heap at St. Paul's adit in Kletno. This began another stage in mining activity related to the exploration and extraction of uranium ores, which lasted until the exhaustion of the deposits in 1953. During the functioning of the Kletno-Kopaliny mine in the years 1948-1953, excavations extended for $37 \mathrm{~km}$ in length, including 20 adits and 3 shafts with a depth from 83 to 150 m (Ciężkowski, Gustaw, 2007). From this year, a state company “Arsenic Industry” in Złoty Stok conducted the exploitation of fluorite for 5 years, which finally finished in 1958 (Ciężkowski, 1989).

On the basis of the closed fluorite mine in Kletno, on 1 May 1958 the Bystrzyca Building Stone Plant was established, based in Stronie Śląskie, which began marble extraction in the Kletno I quarry, and a year later in the Kletno II quarry. Around 1960, marble extraction was carried out by a private Stone Extraction and Processing Plant in the place of today's entrance to the cave. In 1964, a geological documentation of the Kletno III quarry indicated that the deposit has resources of 34 million tonnes of marble of the highest quality in the area of Kletno. A year later, marble extraction began in the Kletno III quarry (Ciężkowski, 2006). Due to danger to the visitors to Jaskinia Niedźwiedzia (Bear Cave) during the marble extraction work and use of explosives in the marble quarry Kletno I; a decision was made on 25 February 1993 to quit marble extraction. The mining activity in the Kletno I quarry finished with the end of June 1993.

\section{The geotourist attractions of Kleśnica Valley}

\section{Bear Cave}

Among the numerous natural assets of the Kleśnica Valley, geological forms which owe their formation to the karst phenomena are noteworthy. The most important of these is the Bear Cave (Fig. 2) open to tourists (see Bartuś et al., 2012).

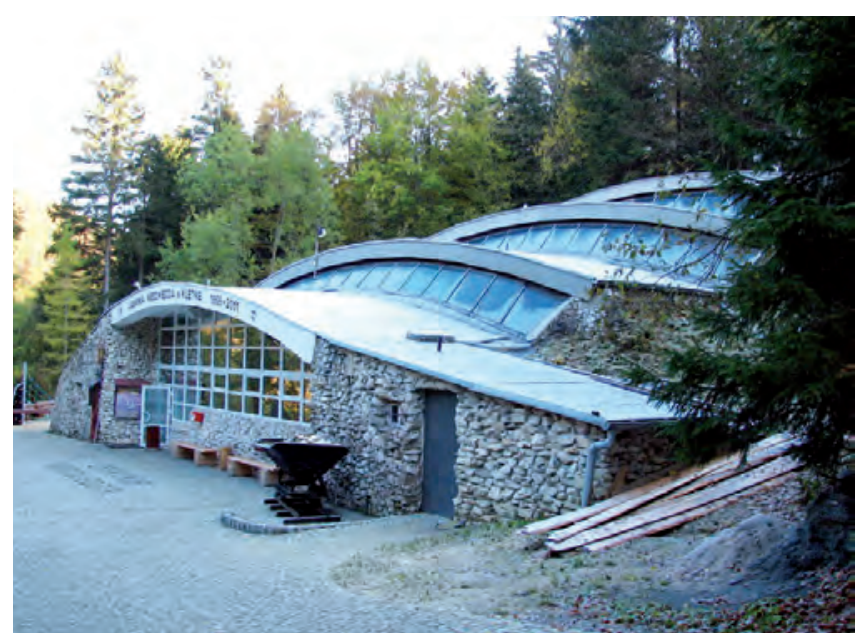

Fig. 2. Hall of Bear Cave in Kletno, phot. A. Marek • Pawilon Jaskini Niedźwiedziej w Kletnie, fot. A. Marek

It is located on the right slope of the Kleśnica Valley and developed in a marble lens on Mount Stroma (1166 m). Within the discussed valley there are also other caves: Biały Kamień, Dudnisko, Sądejowa Szczelina, Miniaturka, Wodna and Cave in Kletno I quarry (Bieroński et al., 2007). These caves are open only to speleologists.

The Bear Cave was discovered accidentally during exploitation works in the marble quarry Kletno III on 14 October 1966. As a result of the blasting of a few holes, the cave opening was uncovered. There, a significant accumulation of animal bones, mostly cave bear, were found (Ciężkowski 2006). The Bear Cave, due to its unique dripstone formations (Fig. 3), along with two inactive quarries and spoil-heaps, and a forest area with rare plant species of undergrowth, were declared in 1977 a nature reserve with a total area of 89.05 ha (Monitor Polski, No. 19, item. 107). 


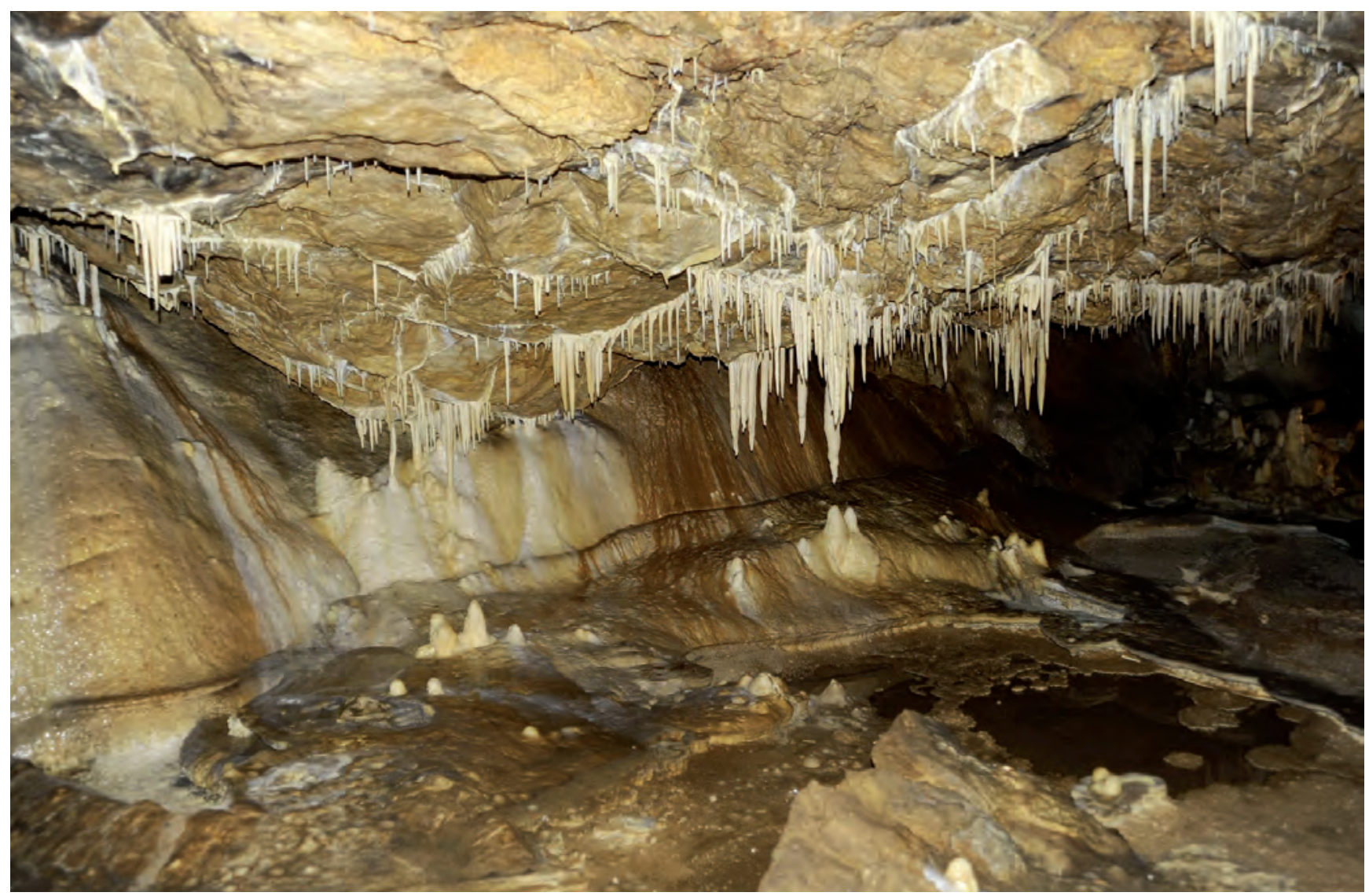

Fig. 3. Dripstone forms in Bear Cave, phot. A. Marek • Formy naciekowe w Jaskini Niedźwiedziej, fot. A. Marek

It was also included in the extent of the Śnieżnik Landscape Park established on 28 October 1981. On 11 June 1983, at 11.00 the cave was opened for tourism.

Bear Cave corridors are on three levels connected to each other by so-called chimneys. Two artificial cave openings lie at an altitude of 793 and $800 \mathrm{~m}$ a.s.l. about 10-15 m above the Kleśnica Valley bottom. The total length of the corridors in the Bear Cave exceeds $2500 \mathrm{~m}$, of which $360 \mathrm{~m}$ are accessible for tourists. The elevation difference between the highest and the lowest point of the cave is $60 \mathrm{~m}$. The Bear Cave represents

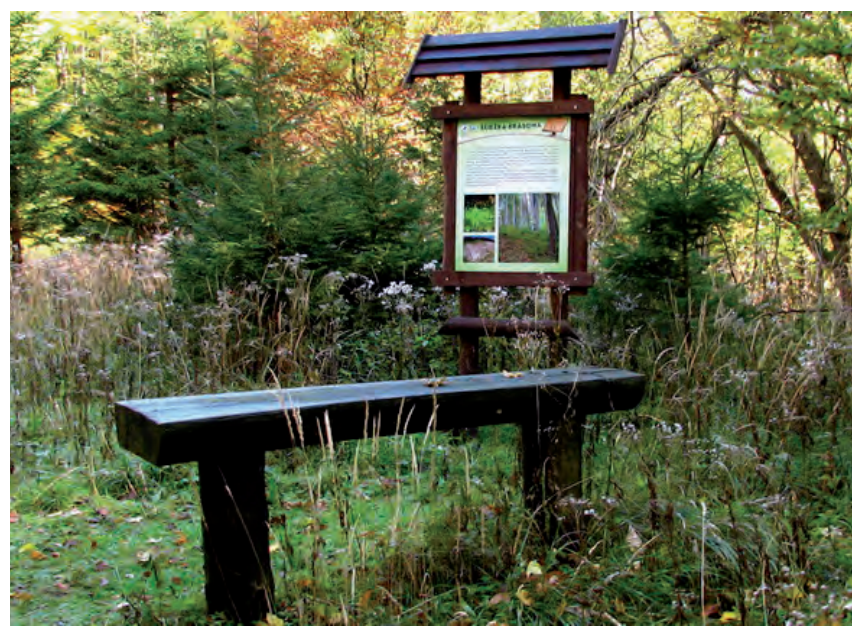

Fig. 4. A stop on the karst path in Kletno, phot. A. Marek • Przystanek ścieżki krasowej w Kletnie, fot. A. Marek the type of large caves (the type embraces caves with a length of 500-5000 m) of horizontal expansion (Pulina, 1999). The central level is open to the public. In the vicinity of the Bear Cave reserve, a Karst Path was designed in order to present the geological structure, karst phenomena and protected plants (Fig. 4). The path length is over $2.5 \mathrm{~km}$.

\section{Marianna Spring}

The Marianna Spring provides water spontaneously flowing from a bore-hole of a depth of $120 \mathrm{~m}$ (Fig. 5).

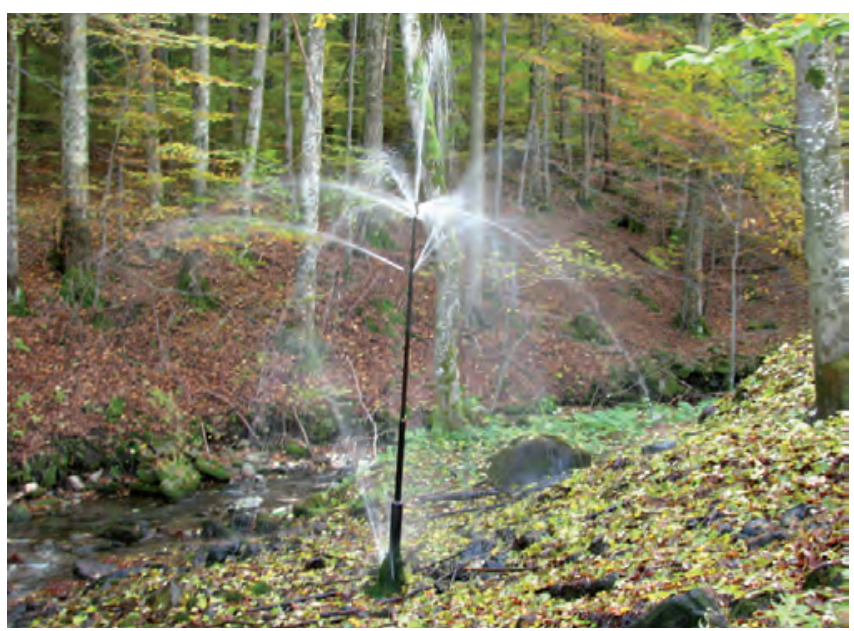

Fig. 5. Marianna Spring in Kleśnica Valley, phot. A. Marek • Źródło Marianna w Dolinie Kleśnicy, fot. A. Marek 
This drilling was performed in 1955 during a mining operation aimed at the exploration of fluorite deposits. The water flows out at $6 \mathrm{l} / \mathrm{sec}$. Water temperature is $6.5^{\circ} \mathrm{C}$, its $\mathrm{pH}$ is 8.2 . This is an example of low-mineralised water and its chemical composition and physical properties are formed within a hundred-meter layer of mica schists and a final layer of marbles. The sum of the components dissolved in water is $139.4 \mathrm{mg} / \mathrm{dm}^{3}$, and the chemical composition is made of cations: $\mathrm{Na}^{+}\left(2.2 \mathrm{mg} / \mathrm{dm}^{3}\right), \mathrm{K}^{+}\left(0.7 \mathrm{mg} / \mathrm{dm}^{3}\right), \mathrm{Ca}^{2+}\left(17.6 \mathrm{mg} / \mathrm{dm}^{3}\right)$, $\mathrm{Mg}^{2+}\left(8.8 \mathrm{mg} / \mathrm{dm}^{3}\right)$ and anions: $\mathrm{Cl}^{-}\left(4.4 \mathrm{mg} / \mathrm{dm}^{3}\right), \mathrm{SO}_{4}^{2-}$ $\left(8.5 \mathrm{mg} / \mathrm{dm}^{3}\right), \mathrm{HCO}_{3}^{-}\left(79.8 \mathrm{mg} / \mathrm{dm}^{3}\right), \mathrm{NO}_{3}^{-}\left(6.9 \mathrm{mg} / \mathrm{dm}^{3}\right)$ and $\mathrm{H}_{2} \mathrm{SiO}_{4}\left(10.4 \mathrm{mg} / \mathrm{dm}^{3}\right)$ (information board).

\section{Marble quarries}

Marble quarries Kletno I and Kletno II, situated in the upper part of the Kleśnica Valley are organized objects remaining after mining activity (Figs. 6, 7). The quarries expose rocks of the Stronie Formation - marble lenses of a thickness of several tens of meters, folded in isoclinal folds, surrounded by schists. The Kletno I quarry was used as a site of a tourist event "Summer of cavemen". In winter the chamois (Rupicapra rupicapra) can be observed in the Kletno I and II quarries.

\section{Museum of the Earth}

It is a small private museum, which presents specimens of minerals, rocks and fossils from Poland and the world. A rich collection of minerals from Lower Silesia, fossilized dinosaur nests with eggs and fossilized life forms of flora and fauna from before 250 million years is noteworthy.

\section{Spoil-heaps}

The spoil-heaps that remained after the extraction of minerals from the Middle Ages up to modern times are very clearly visible in the landscape of the Kleśnica Valley. One of them, located near the car park and the crossroads, has been used for several years as a place where championships in searching minerals are held in August (Fig. 8).

\section{Fluorite adit}

The adit is located at an altitude of $783 \mathrm{~m}$ a.s.l., on the north-eastern slope of Żmijowiec in the Śnieżnik Massif at the road connecting Kletno with Sienna. After more than two years of preparation the adit was opened to tourists on August 4 , 2002. The length of the tourist route is approximately $200 \mathrm{~m}$. The adit displays the natural occurrence of rocks and minerals, such as fluorite, quartz, amethyst, chrysocolla, hematite (Figs. 9, 10). The exhibits (including maps and drawings) present the history of mining and the exploitation of mineral resources in the Kleśnica Valley.

\section{“Gracious Stone” lime kiln}

The "Gracious Stone" lime kiln is located in the lower section of the Kleśnica Valley, near the old marble quarries (Fig. 11). The lime kiln was used for the burning of lime at a high temperature. It belonged to the estate of Marianne of Orange and was probably constructed in the early 19th century, in place of an old lime kiln. It was built on the plan of a hexagon as the work of the famous architect Karl Friedrich Schinkel.

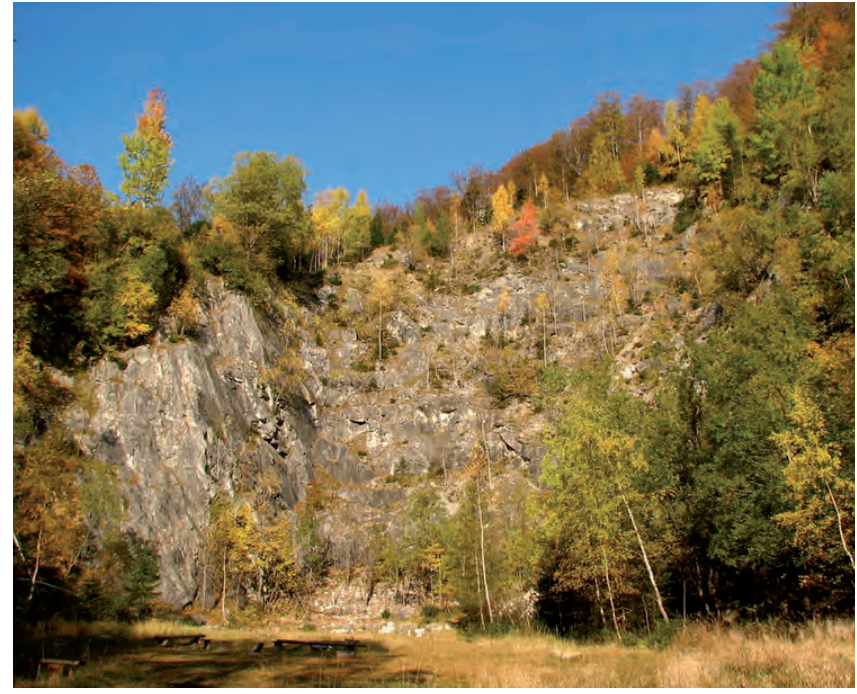

Fig. 6. Kletno II - abandoned marble quarry, phot. A. Marek • Kletno II - nieczynny kamieniołom marmuru, fot. A. Marek

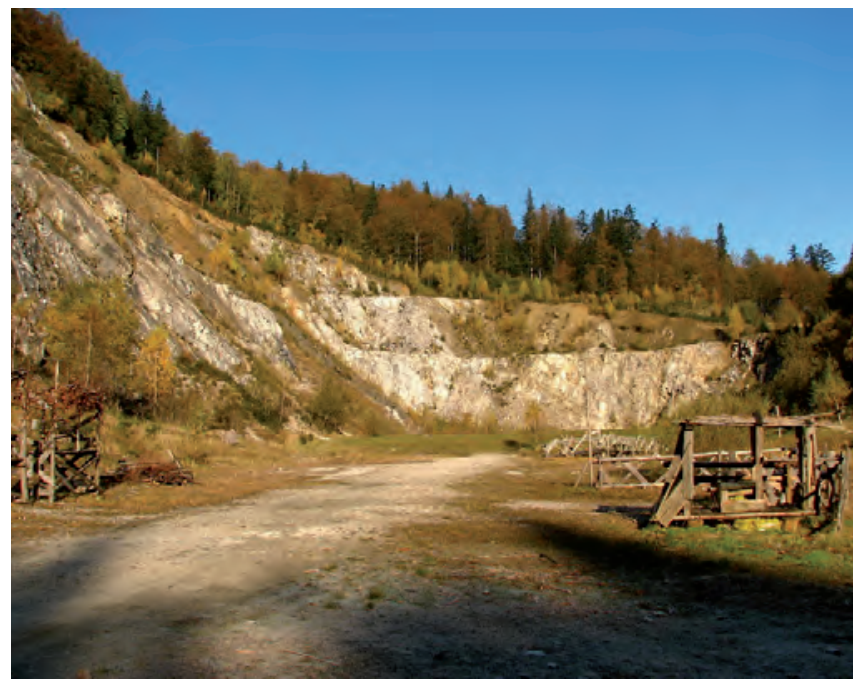

Fig. 7. Kletno I - abandoned marble quarry, phot. A. Marek • Kletno I - nieczynny kamieniołom marmuru, fot. A. Marek

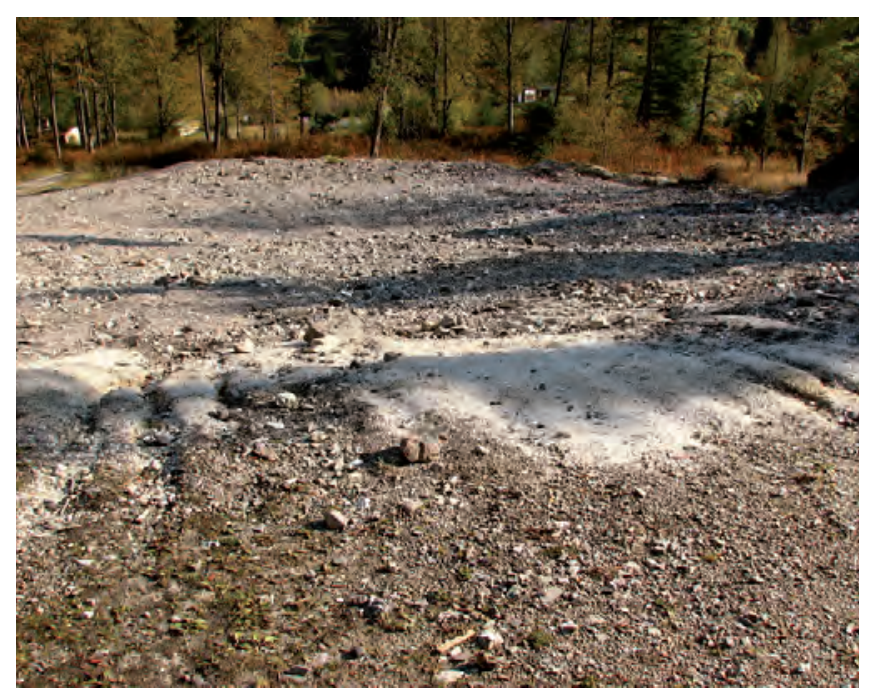

Fig. 8. Spoil-heap in Kletno, phot. A. Marek • Hałda w Kletnie, fot. A. Marek 


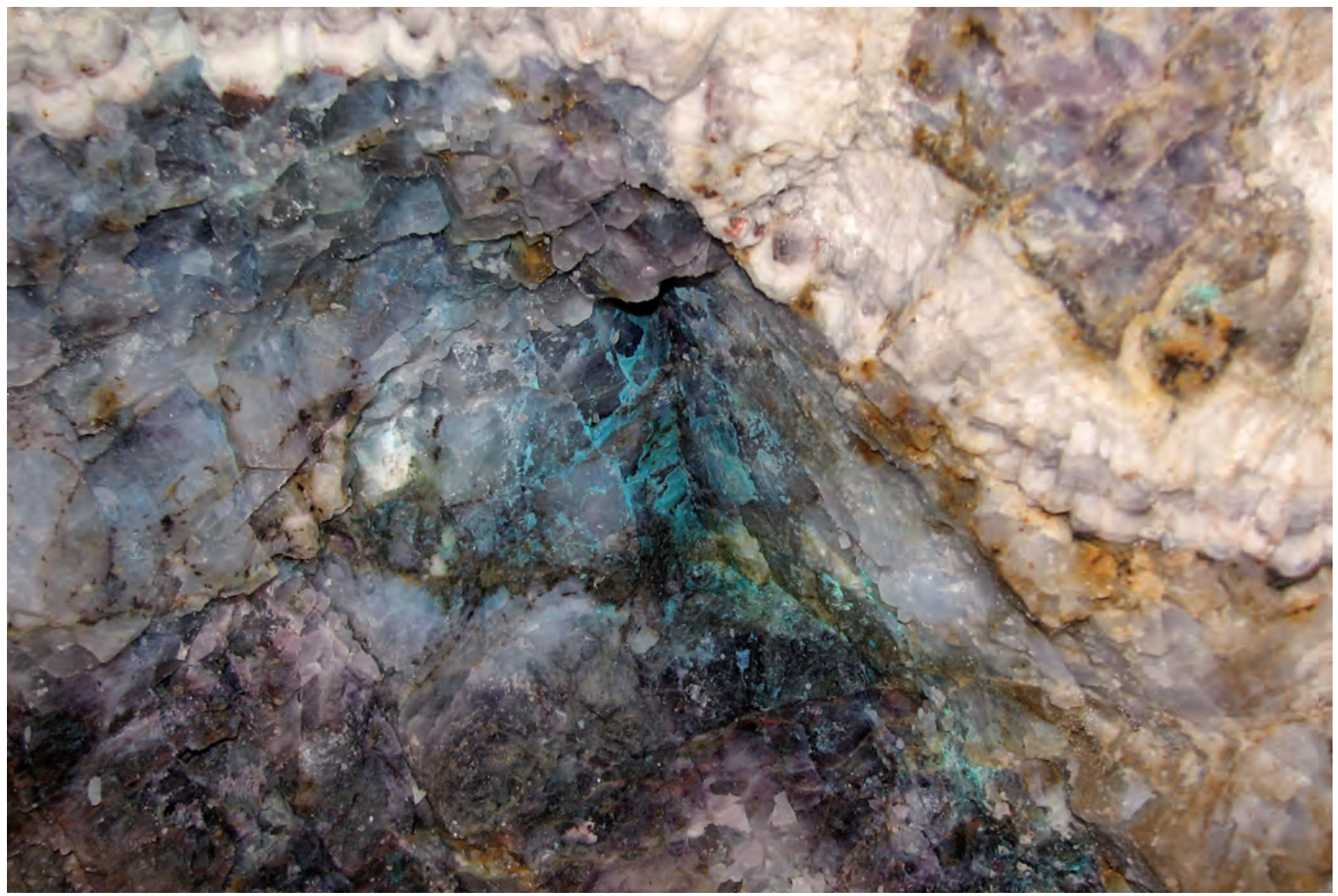

Fig. 9. Chrysocolla and fluorite from the fluorite adit, phot. A. Marek • Chryzokola i fluoryt ze sztolni fluorytowej, fot. A. Marek

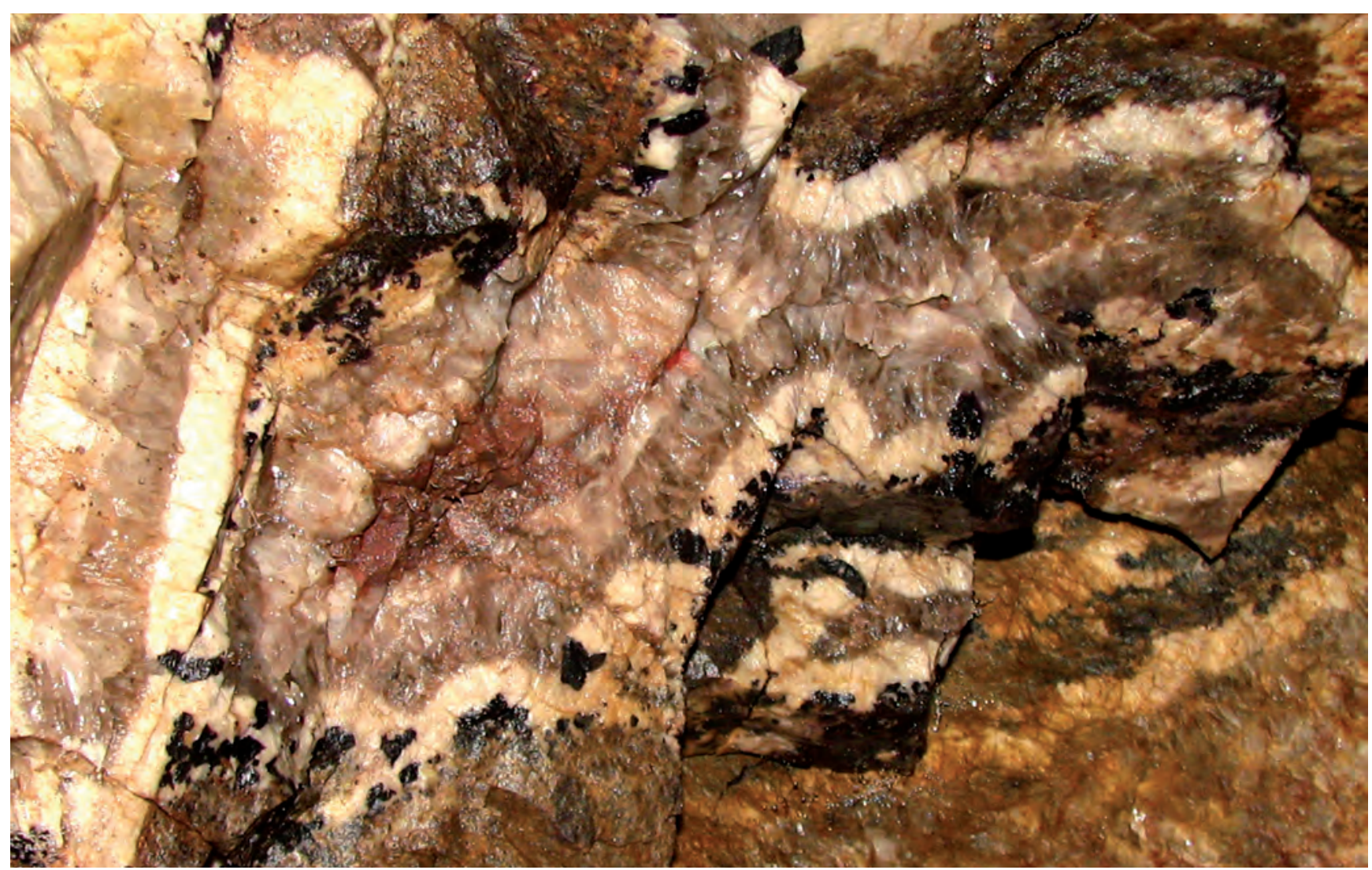

Fig. 10. Quartz (milky and smoky) and hematite from fluorite adit, phot. A. Marek • Kwarc (mleczny i dymny) i hematyt ze sztolni fluorytowej, fot. A. Marek 


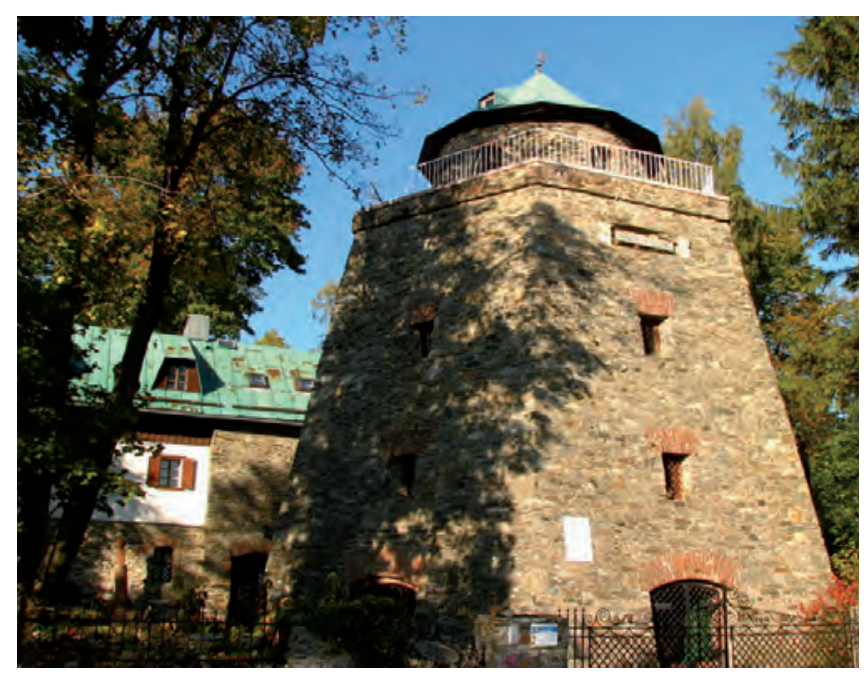

Fig. 11. „Gracious Stone” lime kiln in Kletno, phot. A. Marek • Wapiennik „Łaskawy Kamień” w Kletnie, fot. A. Marek
It performed its industrial function until 1924, and then to 1945 it housed a primitive youth hostel. In the 1950s there were attempts to restore it to its former industrial function, which failed and the object fell into disrepair. In 1978, the historic building was adapted by the Rybczyński family who, following the renovation of the buildings, gave it an exhibition residential function. Since 1980 cultural events, exhibitions and concerts are held in the lime kiln (Rybczyński, 1998).

\section{Assessment of geotourist objects and tourism in the Kleśnica Valley}

One of the methods of determining geotourist attractiveness is objects' assessment. It involves drawing up criteria and characteristics, and assigning them to a point scale that will allow comparing the geotourist attractiveness of different objects.

Tab. 1. Evaluation range and estimate in geotourism evaluation (source: Ihnatowicz, A., et al., 2011) • Kryteria i ocena punktowa obiektów geoturystycznych (źródło: Ihnatowicz, A., et al., 2011)

\begin{tabular}{|c|c|c|}
\hline $\begin{array}{l}\text { Criterion } \\
\text { Kryterium }\end{array}$ & $\begin{array}{l}\text { Attributes } \\
\text { Cechy }\end{array}$ & $\begin{array}{l}\text { Value (in points) } \\
\text { Wartość punktowa }\end{array}$ \\
\hline \multirow{3}{*}{ 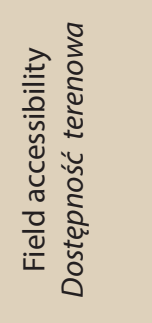 } & $\begin{array}{l}\text { High: geosites located close to the tourist route (up do the range of } 500 \mathrm{~m} \text { ) } \\
\text { Wysoka: stanowisko leżące przy szlaku turystycznym lub w promieniu } 500 \mathrm{~m}\end{array}$ & 3 \\
\hline & $\begin{array}{l}\text { Medium: geosites located distant from touristic route, approx. } 10 \text { minutes of walk } \\
\text { Średnia: stanowisko położone w oddaleniu od szlaku, dojście do } 10 \text { minut marszu }\end{array}$ & 2 \\
\hline & $\begin{array}{l}\text { Low: geosites located far away from touristic route, long difficult walk } \\
\text { Niska: stanowisko położone z dala od szlaku lub długie utrudnione dojście }\end{array}$ & 1 \\
\hline \multirow{3}{*}{ 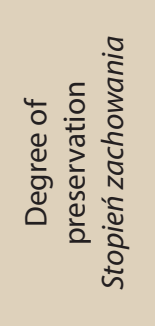 } & $\begin{array}{l}\text { High: well preserved, visible geological structures, undamaged } \\
\text { Wysoki: dobrze zachowane, czytelne struktury geologiczne, niezniszczone }\end{array}$ & 3 \\
\hline & $\begin{array}{l}\text { Medium: low visible geological structures, partly degradated } \\
\text { Średni: mało czytelne struktury geologiczne, częściowa degradacja }\end{array}$ & 2 \\
\hline & $\begin{array}{l}\text { Low: very low visible geological structures, signifficant degradation } \\
\text { Niski: bardzo słabo czytelne struktury geologiczne, znaczna degradacja }\end{array}$ & 1 \\
\hline \multirow{3}{*}{ 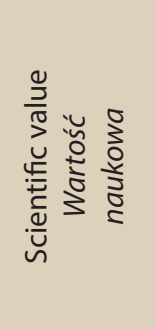 } & $\begin{array}{l}\text { High: unique site of regional importance, many publications } \\
\text { Wysoka: unikatowe stanowisko w skali regionalnej, duża liczba publikacji }\end{array}$ & 3 \\
\hline & $\begin{array}{l}\text { Medium: regional importance, described in publications } \\
\text { Średnia: istotne dla regionu, opisywane w publikacjach naukowych }\end{array}$ & 2 \\
\hline & $\begin{array}{l}\text { Low: local importance, small amount of publications } \\
\text { Niska: znaczenie lokalne, mała liczba publikacji }\end{array}$ & 1 \\
\hline \multirow{3}{*}{ 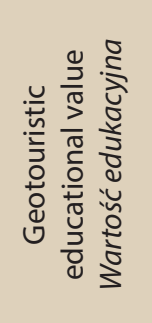 } & $\begin{array}{l}\text { High: showing many geological topics, significant tourist value } \\
\text { Wysoka: jest przykładem wielu zjawisk geologicznych }\end{array}$ & 3 \\
\hline & $\begin{array}{l}\text { Medium: represents a few geological topics of tourist significance } \\
\text { Średnia: jest przykładem kilku zagadnień geologicznych, ma walory turystyczne }\end{array}$ & 2 \\
\hline & $\begin{array}{l}\text { Low: represents small amount of geological topics, no touristic value } \\
\text { Niska: jest przykładem niewielu zagadnień geologicznych, nie ma walorów turystycznych }\end{array}$ & 1 \\
\hline
\end{tabular}


Tab 2. Assessment of objects in the Kleśnica Valley • Waloryzacja obiektów w Dolinie Kleśnicy

\begin{tabular}{|c|c|c|c|c|c|}
\hline $\begin{array}{l}\text { Objects } \\
\text { Obiekty }\end{array}$ & $\begin{array}{c}\text { Field } \\
\text { accessibility } \\
\text { Dostępność } \\
\text { terenowa }\end{array}$ & $\begin{array}{c}\text { Degree of } \\
\text { preservation } \\
\text { Stopień } \\
\text { zachowania }\end{array}$ & $\begin{array}{c}\text { Scientific value } \\
\text { Wartość } \\
\text { naukowa }\end{array}$ & $\begin{array}{c}\text { Educational } \\
\text { value } \\
\text { Wartość } \\
\text { edukacyjna }\end{array}$ & $\begin{array}{c}\text { Total } \\
\text { Razem }\end{array}$ \\
\hline $\begin{array}{l}\text { Bear's Cave } \\
\text { Jaskinia Niedźwiedzia }\end{array}$ & 3 & 3 & 3 & 3 & 12 \\
\hline $\begin{array}{l}\text { Marianna Spring } \\
\text { Źródło Marianna }\end{array}$ & 3 & 2 & 1 & 1 & 7 \\
\hline $\begin{array}{l}\text { Marble quarries } \\
\text { Kamieniołomy marmuru }\end{array}$ & 3 & 2 & 1 & 2 & 8 \\
\hline $\begin{array}{l}\text { Museum of the Earth } \\
\text { Muzeum Ziemi }\end{array}$ & 3 & 1 & 1 & 2 & 7 \\
\hline $\begin{array}{l}\text { Fluorite Adit } \\
\text { Sztolnia Fluorytowa }\end{array}$ & 2 & 2 & 2 & 3 & 9 \\
\hline $\begin{array}{l}\text { "Gracious Stone" Lime kiln } \\
\text { Wapiennik „Łaskawy Kamień" }\end{array}$ & 3 & 2 & 1 & 1 & 7 \\
\hline
\end{tabular}

The criteria, which characterise potentially attractive objects include: location accessibility, degree of preservation, scientific and educational value and the state of tourism development (Ihnatowicz et al., 2011). The above criteria were used to perform the assessment of objects in the Kleśnica Valley (Tab. 1, 2). Kletno can be accessed by district road No. 3256 D from Stara Morawa. It runs through the Kleśnica Valley to the intersection with the communal road in the direction of Sienna. There is a car park operated by PTTK (Polish Tourist and Sightseeing Society) in Stronie Śląskie. A major difficulty for non-motorised tourists is a lack of bus connection from Stronie Śląskie to Kletno. A network of hiking trails has been established for tourists. A yellow hiking trail goes through the discussed area. It begins at the bus stop in Stronie Śląskie and ends at the shelter-house on the Hala pod Śnieżnikiem (walking time of about 4 hours). In the Kleśnica Valley and adjacent areas, several bike and cross-country skiing trails have been established, facilitating the practicing of qualified tourism.

Kletno is a village with low density building development, hence the uneven distribution of accommodation in the Kleśnica Valley as well as large differences in the standard.

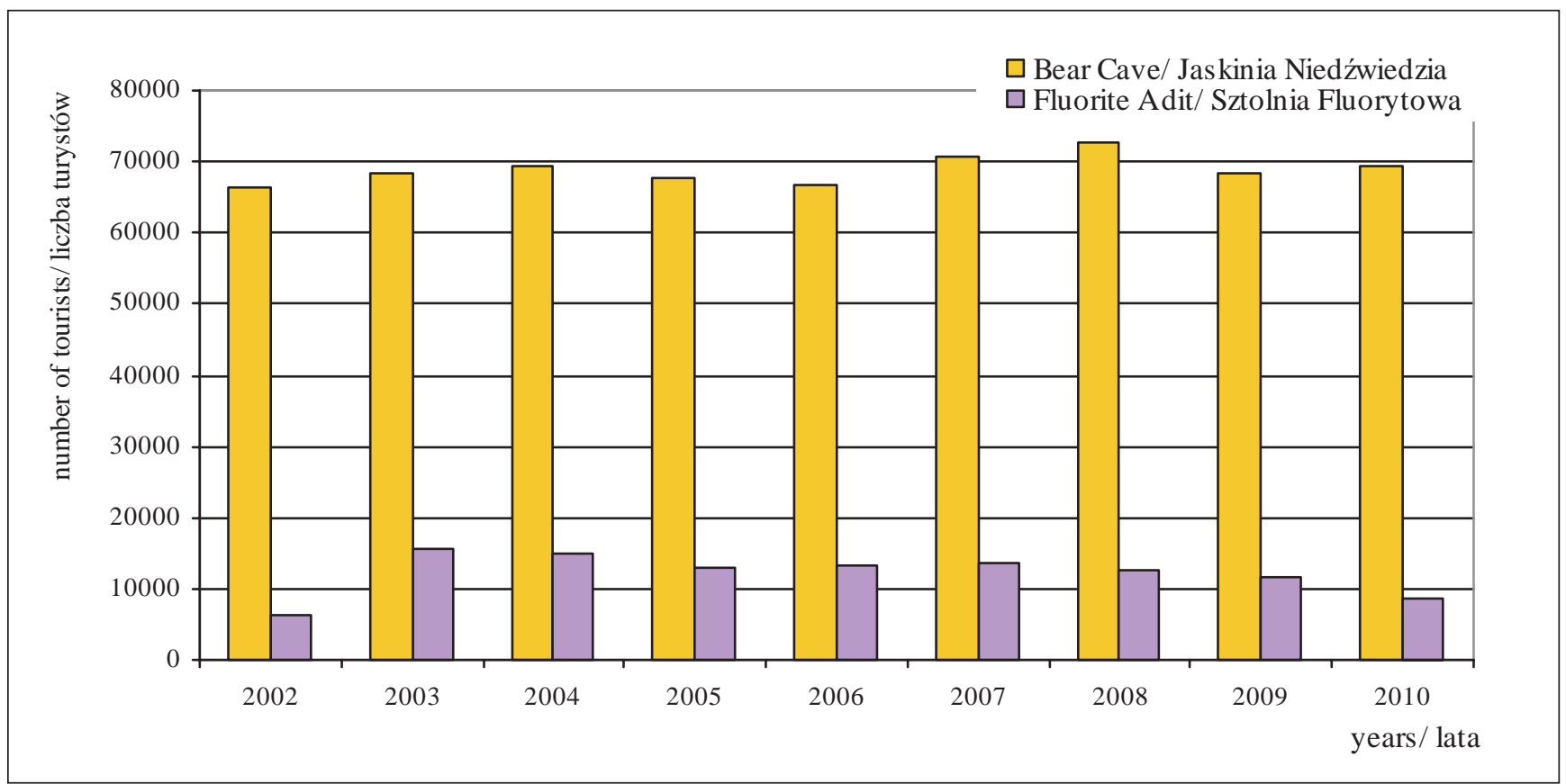

Fig. 12. The number of tourists visiting the Bear Cave and Fluorite Adit (according to Marek, 2011) • Liczba turystów odwiedzających Jaskinię Niedźwiedzią i Sztolnię Fluorytową (według Marek, 2011) 
The geological location of Kletno and the consequent occurrence of numerous unique objects, as well as valuable natural assets of the Kleśnica Valley have made the area a site of scientific research. Particular objects are of interest to paleontologists, geologists, mineralogists, chiropterologists, hydrologists, climatologists and many other scientists. The research has brought about a number of scientific papers published in Polish and foreign journals (see Bartuś et al., 2012). Geotourist objects have an educational value. They have become a place of educational activity for students and tourists.

The major tourist attraction is the Bear Cave. Annually, the object is visited by 67,000 people, while the fluorite adit by 12,190 tourists (Fig. 12). The heaviest tourist traffic occurs in spring, summer and winter (Marek, 2011).

\section{Conclusion}

The existing facilities and thematic paths in the Kleśnica Valley are important points on geotourist routes. There is also a thematically diverse educational element for children and young people, students and academics. In Kletno, fieldwork activities are held for students of various fields, e.g. geology, regional geography, tourist geography, of various universities as well as educational activities for primary and post-primary school students. The accumulation of geological objects in a small area and the exceptional tourist assets account for the unique character of the Kleśnica Valley on a scale of Poland and Europe. The development of tourism in the Kleśnica Valley should involve a focus on environmental values, and especially geotourist ones. $\square$

\section{Streszczenie}

\section{Atrakcje geoturystyczne doliny Kleśnicy}

\section{Stanisław Koszela, Aneta Marek}

\section{Wstęp}

Geoturystyka to połączenie zagadnień z zakresu edukacji, rekreacji, wypoczynku. Jest ona ukierunkowana na poznawanie obiektów i zrozumienie zjawisk oraz procesów geologicznych (www.mos.gov.pl). Geoturystyka łączy wiedzę na temat ruchu turystycznego, obiektów geologicznych oraz materiałów, metod, narzędzi i technik poznawczych (Miśkiewicz et al., 2007). Z uwagi na swoją różnorodność geoturystyka wiąże się często z uprawianiem turystyki kwalifikowanej, turystyki aktywnej czy rekreacji (Gray, 2004).

\section{Położenie geograficzne doliny Kleśnicy}

Dolina Kleśnicy położona jest w Sudetach Wschodnich w mikroregionie Masywu Śnieżnika (Fig. 1). Dolina ma długość 8,7 km i ukształtowana jest przez potok Kleśnica, wypływający z północnych stoków Śnieżnika, z wysokości ok. 1210 m n.p.m.

W dolinie Kleśnicy wyróżnić można trzy odcinki zróżnicowane geomorfologicznie:

- odcinek górny od źródeł do 0,6km biegu, leżący na wysokości 1210-1030 m n.p.m., z zachodzącymi w obrębie koryta potoku procesami stokowymi, ze średnim spadkiem 300\%;

- środkowy od 0,6 do 3,3 km biegu, położony na wysokości 1030-730 m n.p.m., z widoczną doliną, na dnie której w wyniku wezbrań zaczyna pojawiać się terasa akumulacyjna, i dominującą erozją wgłębną, ze średnim spadkiem 111 \%; - dolny od 3,3, do 8,7 km biegu, leżący na wysokości 730534 m n.p.m. cechujący się występowaniem terasy akumulacyjnej, ze średnim spadkiem 36,3\% (Bieroński, 1989).

\section{Budowa geologiczna doliny Kleśnicy}

Kopuła orlicko-śnieżnicka jest jednostką geologiczną Sudetów Zachodnich oddzieloną od Sudetów Wschodnich nasunięciem ramzowskim (Teisseyre, 1968). Rów górnej Nysy dzieli kopułę na część zachodnią - metamorfik Gór Bystrzyckich i Orlickich oraz wschodnią - metamorfik Śnieżnika. Uskoki Stare Mesto-Kletno i Bielice-Stronie dzielą metamorfik Śnieżnika na bloki Gór Złotych i Bialskich, Krowiarek oraz Śnieżnika.

Metamorfik Śnieżnika zbudowany jest ze skał metamorficznych: grupy Młynowca-Stronia, formacji gnejsów śnieżnickich i formacji gnejsów gierałtowskich (Smulikowski, 1979; Don et al., 1990). Wiek skał formacji łupkowych przyjmuje się na górny proterozoik - dolny kambr, natomiast wiek formacji gnejsowych (na podstawie datowań izotopowych) na około 500 Ma. Skały metamorfiku Śnieżnika były metamorfizowane również $\mathrm{w}$ warunkach wysokociśnieniowego metamorfizmu około 352-329 Ma, o czym świadczą wystąpienia granulitów i eklogitów (Żelaźniewicz, 2003).

W górnej części doliny Kleśnicy występują skały formacji Stronia - głównie łupki łyszczykowe wraz z soczewami marmurów (kamieniołomy Kletno I-IV), w których rozwinęły się systemy krasowe Kleśnicy. Marmury są sfałdowane w postaci izoklinalnych fałdów, obalonych w kierunku zachodnim. Są to głównie marmury kalcytowo-dolomitowe i dolomitowe (Koszela, 1998). W środkowej części dolina Kleśnicy przecina strefę dyslokacyjną Stare Mesto-Kletno, z którą związane jest występowanie mineralizacji Fe, U i F (Banaś, 1963). Wśród skał strefy dyslokacyjnej występują zarówno gnejsy śnieżnickie, jak i łupki łyszczykowe z wkładkami marmurów, erlanów, amfibolitów oraz żyły kwarcowe z fluorytem i hematytem. W dolnej części dolina Kleśnicy przecina skały (łupki) formacji Stronia.

Badania hydrogeologiczne w dolinie Kleśnicy wskazują na przepływ części wód powierzchniowych Kleśnicy na południe do doliny Morawy po stronie czeskiej. Zjawisko to jest spowodowane specyficzną budową geologiczną oraz szczelinowo-krasowym środowiskiem wód podziemnych rozwiniętym w spękanych tektonicznie i skrasowiałych marmurach (Kryza, 1982).

\section{Historia górnictwa w dolinie Kleśnicy}

Pierwsze wzmianki wskazujące na tradycje górnictwa omawianego obszaru pochodzą z 1347 r. Wspomina się 
o nazwie die Clesse, co mogło oznaczać narzędzie lub miejsce do kruszenia rud. Przyjmuje się, że nazwa ta dała początek wsi Klessengrund i potokowi Klessenbach, co oznacza obecnie Kletno i Kleśnica (Ciężkowski et al., 1996).

Na rozwój górnictwa i hutnictwa w Masywie Śnieżnika wpływ miał dokument wydany w 1497 r. przez księcia ziębickiego Henryka Starszego, ustanawiający wolność poszukiwań górniczych (Ciężkowski, 1989). W XVI w. pojawiło się kilka wzmianek o kopalniach w Masywie Śnieżnika. O istnieniu sztolni w Kletnie świadczą dokumenty z 1520 r. (Sztolnia św. Pawła), 1521 r. (Sztolnia św. Jakuba) i w 1577 r. o Sztolni Mrocznej, w której stwierdzono występowanie rud srebra. Działalność górniczą w Kletnie, Marcinkowie i Bolesławowie przerwała wojna trzydziestoletnia (1618-1648). Po ponownym uruchomieniu eksploatacji rud miedzi po $1656 \mathrm{r}$. w końcu XVII w. nastąpił upadek górnictwa w tym rejonie (Gluziński, 1960). Prace górnicze zostały wznowione na kilka lat po 1839 r. z inicjatywy Marianny Orańskiej, księżniczki niderlandzkiej, właścicielki Stronia Śląskiego, Kamieńca Ząbkowickiego i Złotego Stoku.

Kolejny okres działalności górniczej związanej z poszukiwaniem i eksploatacją rud uranu, nastąpił w 1947 r. na mocy umowy polsko-radzieckiej i trwał aż do wyczerpania się tych złóż w 1953 r. W trakcie działalności kopalni Kletno-Kopaliny w latach 1948-1953 wykonano wyrobiska o długości 37 km, w tym 20 sztolni i trzy szyby o głębokości od 83 do 150 m (Ciężkowski, Gustaw, 2007). Od 1953 roku Państwowe Przedsiębiorstwo „Przemysł Arsenowy” w Złotym Stoku prowadziło eksploatację fluorytu, którą zakończono w 1958 r. (Ciężkowski 1989). Na bazie zlikwidowanej kopalni fluorytu w Kletnie powstały w 1958 r. Bystrzyckie Zakłady Kamienia Budowlanego z siedzibą w Stroniu Śląskim, które eksploatowały marmury w kamieniołomie Kletno I do końca czerwca 1993 r. (Ciężkowski, 2006).

\section{Geostanowiska i atrakcje geoturystyczne doliny Kleśnicy}

\section{Jaskinia Niedźwiedzia}

Głównym elementem przyrodniczym doliny Kleśnicy jest rozwinięta w soczewie marmurów na górze Stromej (1166 m n.p.m.) Jaskinia Niedźwiedzia (Fig. 2). Jaskinia została odkryta podczas prac eksploatacyjnych w kamieniołomie marmuru Kletno III 14 października 1966 r., a jej otwarcie dla ruchu turystycznego nastąpiło 11 czerwca 1983 r. (Ciężkowski, 2006, Bartuś et al., 2012). Reprezentuje ona typ jaskini o rozwinięciu horyzontalnym (Pulina, 1999). Łączna długość korytarzy w Jaskini Niedźwiedziej przekracza $2500 \mathrm{~m}$, a dla ruchu turystycznego udostępniono 360 m korytarzy (Fig. 3).

Jaskinię Niedźwiedzią wraz z dwoma nieczynnymi kamieniołomami i hałdami oraz obszarem lasu z rzadkimi gatunkami roślin runa uznano w 1977 r. za rezerwat przyrody o łącznej powierzchni 89,05 ha (Monitor Polski nr 19, poz. 107).

W sąsiedztwie jaskini została wytyczona dydaktyczna ścieżka krasowa prezentująca budowę geologiczną i zjawiska krasowe oraz rośliny chronione rezerwatu. Długość ścieżki wynosi ponad 2,5 km (Fig. 4). W dolinie Kleśnicy znane są również inne jaskinie: Biały Kamień, Dudnisko, Sądejowa
Szczelina, Miniaturka, Jaskinia Wodna i Jaskinia w Kletnie (Bieroński, Socha, Stefaniak, 2007).

\section{Źródlo Marianna}

Źródło Marianna jest samoczynnie wypływającą wodą z odwiertu o głębokości 120 m. (Fig. 5). Odwiert ten wykonano w 1955 r. podczas górniczej działalności związanej z poszukiwaniem złóż fluorytu. Woda o temperaturze $6,5^{\circ} \mathrm{C}$ i pH 8,2 wypływa w ilości 6 l/s. Woda jest przykładem wody słabo zmineralizowanej, a jej skład chemiczny i właściwości fizyczne formują się w obrębie stumetrowej warstwy łupków łyszczykowych i końcowej warstwy marmurów (tablica informacyjna).

\section{Kamieniolomy marmurów}

W nieczynnych kamieniołomach Kletno I i Kletno II odsłaniają się marmury w otoczeniu łupków, o miąższości kilkudziesięciu metrów, zafałdowane w izoklinalne fałdy (Fig. 6, 7). Przez kilka lat w kamieniołomie Kletno I odbywała się impreza turystyczna „Lato jaskiniowców”. W okresie zimowym w kamieniołomach Kletno I i Kletno II można zaobserwować pojawiające się tam kozice ( $R u$ picapra rupicapra).

\section{Muzeum Ziemi Geologiczne - Kletno}

W Muzeum Ziemi prezentowane są minerały, skały i skamieniałości, wśród których na uwagę zasługują bogate zbiory z Dolnego Śląska, skamieniałe gniazda z jajami dinozaurów oraz skamieniałe formy życia flory i fauny sprzed 250 milionów lat.

\section{Halda}

Na obszarze jednej z hałd, które pozostały po eksploatacji kopalin od średniowiecza do czasów współczesnych, odbywają się latem mistrzostwa w poszukiwaniu minerałów (Fig. 8).

\section{Sztolnia Fluorytowa}

Sztolnia Fluorytowa położona jest na wysokości $783 \mathrm{~m}$ n.p.m., na północno-wschodnim zboczu Żmijowca w Masywie Śnieżnika przy drodze łączącej miejscowość Kletno z Sienną. Sztolnię udostępniono dla ruchu turystycznego 4 sierpnia 2002 r. W sztolni, wzdłuż trasy turystycznej o długości ok. 200 m, można obserwować naturalne wystąpienia skał i minerałów (Fig. 9, 10). Eksponowane są również obiekty (m.in. mapy, ryciny, eksponaty) prezentujące historię górnictwa i eksploatacji surowców mineralnych w dolinie Kleśnicy.

\section{Wapiennik „Laskawy Kamień"}

Wapiennik (piec wapienny) „Łaskawy Kamień” (Fig. 11) jest położony w dolnym odcinku doliny Kleśnicy. Należał do majątku Marianny Orańskiej i powstał prawdopodobnie na początku XIX w., w miejscu starego wapiennika. Zbudowany został na planie sześcioboku jako dzieło znanego architekta Karla Friedricha Schinkla. Funkcję przemysłową pełnił do 1924 r., a następnie, do 1945 r., mieściło się w nim prymitywne schronisko młodzieżowe. W 1978 r. zabytkowy obiekt zaadaptowała do celów wystawienniczo-mieszkalnych rodzina 
Rybczyńskich. Od 1980 r. w wapienniku odbywają się wydarzenia kulturalne, wystawy i koncerty muzyczne (Rybczyński, 1998).

\section{Waloryzacja obiektów geoturystycznych i ruch turystyczny w Dolinie Kleśnicy}

Jedną z metod określających atrakcyjność geoturystyczną jest waloryzacja obiektów. Polega ona na opracowaniu kryteriów i cech oraz przyporządkowaniu im skali punktowej, która pozwoli porównać atrakcyjność geoturystyczną różnych obiektów. Do kryteriów, które charakteryzują obiekty potencjalnie atrakcyjne zaliczono: dostępność terenową, stopień zachowania obiektu, wartość naukową i edukacyjną (Ihnatowicz et al., 2011).

Powyższe kryteria zastosowano do przeprowadzenia waloryzacji obiektów w dolinie Kleśnicy (Tab. 1, 2). Do Kletna prowadzi droga powiatowa nr 3256 D ze Starej Morawy. Biegnie ona doliną Kleśnicy aż do skrzyżowania z drogą gminną w kierunku miejscowości Sienna. Tam też znajduje się parking obsługiwany przez PTTK w Stroniu Śląskim. Poważnym utrudnieniem dla turystów niezmotoryzowanych jest brak połączeń komunikacji autobusowej PKS do Kletna ze Stronia Śląskiego. Dla turystów stworzono sieć szlaków turystycznych. Przez omawiany obszar przebiega pieszy żółty szlak turystyczny. Jego początek znajduje się na przystanku PKS w Stroniu Śląskim, a koniec przy schronisku na Hali pod Śnieżnikiem (czas przejścia ok. 4 h). Na terenie doliny Kleśnicy i obszarach sąsiednich utworzono kilka szlaków rowerowych i narciarskich, co umożliwia uprawianie turystyki kwalifikowanej.

Kletno jest wsią o rozproszonej zabudowie, stąd też w dolinie Kleśnicy występuje nierównomierne rozmieszczenie obiektów noclegowych, ale jednocześnie duże ich zróżnicowanie w zakresie standardu.

Położenie geologiczne Kletna i związane z tym występowanie wielu unikatowych obiektów, a także cenne wartości przyrodnicze doliny Kleśnicy sprawiły, że teren ten stał się miejscem badań naukowych. Poszczególne obiekty są miejscem zainteresowań paleontologów, geologów, mineralogów, chiropterologów, hydrologów, klimatologów i wielu innych naukowców. W związku z prowadzonymi badaniami powstało wiele prac naukowych, publikowanych w czasopismach polskich i zagranicznych (zob. Bartuś et al., 2012). Obiekty geoturystyczne mają wartość edukacyjną. Stały się one miejscem zajęć dydaktycznych uczniów i studentów oraz przybywających turystów. Największą atrakcyjność turystyczną ma Jaskinia Niedźwiedzia. Rocznie ten obiekt odwiedza średnio 67000 osób, zaś Sztolnię Fluorytową 12190 turystów (Fig. 12). Największy ruch turystyczny występuje w okresie wiosenno-letnim oraz zimowym (Marek, 2011).

\section{Podsumowanie}

Zróżnicowany zespół obiektów geoturystycznych w dolinie Kleśnicy jest ważnym tematycznie elementem edukacyjnym i badawczym w skali kraju i Europy. W Kletnie odbywają się ćwiczenia terenowe studentów różnych kierunków, np. geologia, geografia regionalna, geografia turystyczna, różnych uczelni oraz zajęcia dydaktyczne uczniów szkół podstawowych i ponadpodstawowych. Nagromadzenie geostanowisk na niewielkim obszarze i wyjątkowe walory turystyczne stanowią o unikalnym charakterze doliny Kleśnicy. Rozwój turystyki w Masywie Śnieżnika powinien przebiegać z poszanowaniem wyjątkowych wartości przyrodniczych doliny Kleśnicy i uwzględniać jej walory geoturystyczne.

\section{References (Literatura)}

Banaś M., 1963. O skarnoidach metamorfiku Śnieżnika Kłodzkiego (Dolny Śląsk). Prace Geologiczne Komisji Nauk Geologicznych PAN, 12: 7-33.

Bartuś T., Bębenek S., Doktor M., Golonka J., Ilcewicz-Stefaniuk D., Joniec A., Krąpiec M., Krobicki M., Łodziński M., Margielewski W., Mastej W., Mayer W., Miśkiewicz K., Słomka E., Słomka T., Stadnik R., Stefaniuk M., Strzeboński P., Urban J., Waśkowska A. \& Welc. E., 2012. Katalog obiektów geoturystycznych w obrębie pomników i rezerwatów przyrody nieożywionej. The catalogue of geotourist sites in nature reserves and monuments. Kraków.

Bieroński J., 1989. Hydrologia zlewni Kleśnicy, In: Jahn A., Kozłowski S., Wiszniowska T. (eds), Jaskinia Niedźwiedzia w Kletnie. Badania i udostępnianie. Ossolineum, Wrocław: 202-220.

Bieroński J., Socha P., Stefaniak K., 2007. Jaskinia Masywu Śnieżnika Kłodzkiego. In: Materiały 41. Sympozjum Speleologicznego, Kletno, 9-21.

Ciężkowski W., 1989. Surowce mineralne Doliny Kleśnicy oraz ich eksploatacja. In: Jahn A., Kozłowski S., Wiszniowska T. (eds), Jaskinia Niedźwiedzia w Kletnie. Badania i udostępnianie. Ossolineum, Wrocław: 137-146.

Ciężkowski W., 2006. Kalendarium Jaskini Niedźwiedziej. In: Ciężkowski W., (ed.), Jaskinia Niedźwiedzia w Kletnie. 40 lat eksploracji, badań, ochrony i turystyki, Wrocław-Kletno: 13-25.

Ciężkowski W., Gustaw A., 2007. Górnictwo podziemne Masywu Śnieżnika - stara kopalnia uranu w Kletnie. In: Materiały 41. Sympozjum Speleologicznego, Kletno: 25-26.
Ciężkowski W., Irmiński W., Kozłowski S., Mikulski S., Przeniosło S., Sylwestrzak H., 1996. Zmiany w litosferze wywołane eksploatacją surowców mineralnych. In: Jahn A., Kozłowski S., Pulina M., (eds), Masyw Śnieżnika - zmiany $w$ środowisku przyrodniczym. Wydawnictwo PAE, Warszawa: 85-119.

Don J., Dumicz M., Wojciechowska I., Żelaźniewicz A., 1990. Geology of the Orlica-Śnieżnik dome, Sudetes. Recent state of knowledge. Neues Jahrbuch für Geologie und Paläontologie - Abhandlung, 179, 2/3: 239-252.

Gluziński W., 1960. Zarys dziejów górnictwa i hutnictwa metali w Kłodczyźnie (XIV-XVII w.). Rocznik Ziemi Kłodzkiej, IV/V: 93-142.

Gray M., 2004. Geodiversity valuing and conserving abiotic nature. Departament of Geography, Queen Mary, University of London, John Wiley \& Sons, London.

Ihnatowicz A., Koźma J., Wajsprych B., 2011. Wałbrzyski Obszar Geoturystyczny - inwentaryzacja geotopów dla potrzeb promocji geoturystyki. Przeglad Geologiczny, 59, 11: 722-731.

Koszela S., 1997. Petrogeneza marmurów z południowo-wschodniej części metamorfiku Śnieżnika. Geologia Sudetica, 30: 59-115.

Kryza H., 1982. Wody podziemne północnej części Masywu Śnieżnika. In: Wspótczesne problemy hydrogeologii regionalnej. II Ogólnopolskie Sympozjum, Lądek Zdrój. Wydawnictwo Uniwersytetu Wrocławskiego, Wrocław: 59-77.

Marek A., 2011. Turystyka w lasach i obszarach chronionych Śnieżnickiego Parku Krajobrazowego. Studia i Materialy Centrum Edukacji Przyrodniczo-Leśnej, 3: 48-53. 
Miśkiewicz K., Doktor M., Słomka T., 2007. Naukowe podstawy geoturystyki - zarys problematyki. Geoturystyka, 4: 3-12.

Monitor Polski nr 19, poz. 107. Zarzadzenie Ministra Leśnictwa i Przemysłu Drzewnego z dnia 21 lipca 1977 w sprawie uznania za rezerwaty przyrody. Pulina M., 1999. Kras formy i procesy. Wydawnictwo Uniwersytetu Śląskiego, Katowice.

Rybczyński J., 1998. Wapiennik „Łaskawy Kamień”. Szkic do rozważań In: Janicki A. (red.), Stronie Śląskie i jego wsie gminne. Urząd Miejski w Stroniu Śląskim, Stronie Śląskie, 69-73.

Smulikowski K., 1979. Ewolucja polimetamorficzna krystaliniku Śnieżnika Kłodzkiego i Gór Złotych w Sudetach. Geologia Sudetica, XIV (1): 7-76.
Teisseyre H., 1968. Serie metamorficzne Sudetów. Geologia Sudetica, IV: 7-37.

Żelaźniewicz A., 2003. Postęp wiedzy o geologii krystaliniku Sudetów w latach 1990-2003. In: Ciężkowski A., Wojewoda J., Żelaźniewicz A., Sudety Zachodnie: od wendu do czwartorzędu. Wydawnictwo WIND, Wrocław: 7-17.

website (strona internetowa):

www.mos.gov.pl/kategoria/2372_geologia_dla_turystyki 